УДК 343.97

DOI https://doi.org/10.32837/pyuv.v1i4(29).410

\author{
І. В. Однолько \\ orcid.org/0000-0002-4896-4728 \\ кандидат юридичних наук, доцент, \\ викладач відділу підготовки прокурорів з підтрилання публічного обвинувачення в суді \\ Інституту спеиіальної підготовки \\ Національної академї прокуратури України
}

\title{
ШЛЯХИ ПРОТИДІЇ КОРУПЦІЇ В УКРАЇНІ (МЕХАНІЗМ РЕАГУВАННЯ)
}

Постановка проблеми. Аналізуючи явище корупції в Україні, слід чітко усвідомлювати його зв'язок із тією кризою, в якій перебуває наша держава. Тобто існування корупції зумовлюється не лише недосконалістю вітчизняного кримінального законодавства або морально-етичним занепадом у громадянському суспільстві, а й безпосередньо кризовою обстановкою життя людей. Саме за таких умов панування корупції зводяться нанівець усі позитивні зрушення політичного, соціального, економічного чи правового напрямів.

Для ефективної протидії корупції треба брати до уваги зазначену їі особливість - здатність поглиблюватися внаслідок суспільної кризи. Необхідно розуміти, що морально-етичний занепад, спричинений кризою суспільного життя, призводить до створення прошарку людей, для яких сама по собі корупція не $є$ чимось огидливим та неприпустимим, навпаки - $є$ прийнятним та цілком нормальним явищем. Масштаби цієї проблеми неосяжні, адже подібне ставлення до завідомо незаконних дій руйнує загальнонаціональну культуру, що своєю чергою тягне загальне ослаблення нації.

Громадяни Швеції, Австрії чи Німеччини різко негативно ставляться до будь-яких корупційних проявів, на відміну від сучасних українців (більшості з них принаймні).

3 огляду на зазначене в нашій державі треба розробляти адекватні шляхи протидії явищу корупції, враховуючи особливості кризового стану життя суспільства.

Зрозуміло, що дієвий механізм реагування на прояви корупції можливо виробити лише за умови системного підходу до запобігання злочинності подібного роду.

У національній кримінологічній доктрині містяться доволі прогресивні висновки щодо дієвої боротьби із корупційною злочинністю, зокрема, про те, що протидія корупційним проявам має базуватися на взаємопов'язаних профілактичних, правоохоронних і репресивних заходах.

Крім того, антикорупційна політика повинна грунтуватися на розумінні корупції як явища, зумовленого соціальними чинниками. Так, багато дослідників феномену корупції наголошують, що корупція виникає не сама по собі, а на заздалегідь підготовленій соціальній базі [1, с. 116].
Актуальність цього дослідження полягає в тому, що сьогоднішні масштаби й динаміка розвитку корупції в Україні створюють реальну загрозу національній безпеці, й поступово корупція стає глобальною проблемою держави, а отже, потрібно якнайшвидше знайти дієвий механізм реагування на ситуацію, що склалася, та шляхи протидії цьому руйнівному явищу.

Аналіз останніх досліджень та публікацій. Питанням пошуку найбільш результативних шляхів протидії корупції в нашій державі приділяли увагу в своїх дослідженнях такі науковці, як А.П. Закалюк, Х.Ю. Федорчак, О.С. Мельников, М.I. Мельник, О.М. Джужа, О.О. Дудоров, B.М. Попович, В.Я. Тацій та інші.

Мета статті. Ця стаття має за мету окреслити вже наявні шляхи протидії корупційним проявам в Україні та на основі проведеного дослідження запропонувати нові механізми реагування на корупційну злочинність. Аби досягти поставленої мети, висунуто таке завдання: розкрити наукові здобутки вітчизняних та зарубіжних науковців у вивченні питання про загально-правові шляхи подолання корупції та проаналізувати уже застосовані в Україні, а також ті, які варто використати найближчим часом.

Виклад основного матеріалу. Переходячи до викладення основного матеріалу, насамперед зазначимо слушну думку O.М. Костенка про те, що в нашій державі чомусь усвідомлено опускається фактор корупційної активності громадян й так само усвідомлено зосереджується увага на фактоpi корумпованості посадовців та службових осіб [3, с. 137]. Між тим, корупцію як явище утворює не лише особа, яка має доступ до адміністративного ресурсу, а й та особа, яка жадає скористатися цим адміністративним ресурсом за рахунок неправомірної винагороди. В контексті зазначеного можна висловити просту на перший погляд, але влучну за своєю суттю тезу - якщо відсутня пропозиція або обіцянка неправомірної вигоди, то відсутній і суб'єкт, який може її отримати. Натомість у нашому суспільстві спостерігається явище кругової поруки: всі все розуміють, й правила гри, в якій панує політика мовчазної згоди, всіх начебто влаштовують. Дійсно, в нашій державі дуже складно знайти особу, яка б жодного разу 
в своєму житті не вдавалася до дачі хабара. Донедавна подібні «вирішення ситуацій на місці» були популярні у відносинах з працівниками Державної патрульної служби, поки структуру не розформували та не замінили поліцією нової формації, співробітники якої, хочеться вірити, навіть із часом не повернуться до попереднього алгоритму роботи. Також дачі хабара поширені у школах, лікарнях, дитячих садках (для прискорення отримання місця в закладі, бо інакше дитина подорослішає раніше, аніж до неї дійде черга), військових комісаріатах (там за чітко обумовлену суму можна закрити питання проходження строкової служби в лавах української армії) та майже в будь-якій іншій соціальній сфері.

Акумулюючи зазначене вище, доходимо висновку, що в Україні треба здійснювати заходи із зменшення корупційної активності громадян. Утіленням такої діяльності може стати антикорупційне виховання населення як один із підвидів правового виховання населення. Свого часу антикорупційне виховання застосовувалося в місті Палермо, де населенню намагалися прищепити відразу до мафіозних угруповань.

Підвищення соціальної культури громадян разом із дієвою кримінальною юстицією є одним з дієвих механізмів протидії корупційній злочинності [4]. Як певну аксіому вбачають дослідники тезу, що ніякі вдосконалення законодавства чи запровадження більш суворих санкцій нічого не змінять, якщо культура громадян залишиться на тому рівні, на якому вона перебуває нині.

Також слушною є думка професора O.M. Джужі, який зазначає, що з огляду на світовий та вітчизняний досвід протидії корупції найбільшою ефективністю щодо протидії корупційним проявам користується наявність політичної волі, спрямованої на реальну протидію зазначеному виду злочинів. По-друге, треба створити для корупції такі умови, аби вона здавалася ризикованою та невигідною. Наявність суворого покарання, яке буде передбачене за корупційні злочини, повинно змусити людину, яка має можливість здійснити корупційне правопорушення, двічі подумати, а чи потрібен такий ризик, чи є сенс ризикувати в цьому випадку. Головне завдання - дати урядовцям зрозуміти, що розкрадати державні кошти, брати хабарі та вчиняти інші дії корупційного характеру є невигідним, тому що можлива відповідальність значно більш серйозніша за можливу вигоду [5, с. 215].

Цілком зрозуміло, що протидія корупції залежить від загальнонаціональної стратегії держави щодо викорінення цього явища. Від часу здобуття незалежності в Україні видано багато нормативно-правових актів, спрямованих на протидію корупції, проте суттєвих досягнень у вигляді зменшення проявів корупційної злочинності поки що не спостерігається. Широкі стратегічні зміни прийнято та впроваджено в правову доктрину України у 2014 році, коли антикорупційне законодавство зазнало певного реформування. Так, у той період було вперше сформульовано необхідність корупційного моніторингу всередині держави, аргументовано потребу превентивної антикорупційної діяльності та визначено вектор на рішуче переслідування корупційних злочинів.

Зважаючи на сьогоднішній стан, важливим $\epsilon$ той факт, що у квітні 2018 року Кабінет Міністрів України схвалив Державну програму щодо реалізації засад державної антикорупційної політики в Україні (Антикорупційна Стратегія) на 20182020 роки [9]. Головними напрямами антикорупційної політики держави згідно із цією Стратегію є:

- імплементація у вітчизняне антикорупційне законодавство норм ЄС, зокрема тих, що стосуються пошуку та арешту активів осіб, які підозрюються у вчиненні корупційних злочинів;

- запобігання корупційним проявам у правоохоронних органах, представницьких органах влади, у діяльності органів державної влади та органів місцевого самоврядування;

- закладання вектору на впровадження більш жорсткої відповідальності за корупційні правопорушення;

- формування негативного ставлення до корупції як явища.

Роботу в зазначених напрямах реалізують суб'єкти протидії корупції зі спеціальними повноваженнями, такі як Національне антикорупційне бюро України (далі - НАБУ), Національне агентство з питань запобігання корупції, спеціалізована антикорупційна прокуратура, вищий антикорупційний суд тощо.

Звичайно в державі має бути подібний документ, й стратегічні плани щодо боротьби з корупцією повинні оновлюватися, оскільки сама корупція зазнає постійних динамічних змін, проте багато положень зазначеної Стратегії дублюють ті, що вже стали історією. Відтак ця Стратегія та аналогічні їй нормативні документи не окреслюють реальних шляхів протидії корупції в державі.

Цікаві шляхи протидії корупційним проявам в Україні були запропоновані в межах Антикорупційної школи, що відбулася у 2018 році та зібрала багато громадських активістів, які надто болісно ставляться до проблем, пов'язаних із корупцією. Подібні школи проходять в багатьох державах з високим рівнем корумпованості за підтримки Організації Об’єднаних Націй та неприбуткових фондів розвитку молоді [7]. Головними тезами щодо шляхів протидії корупції на зазначеному заході були:

1) усунення конфлікту інтересів та доступ громадськості до інформації. Під усуненням конфлікту інтересів малося на увазі, що під час 
виконання своїх професійних обов'язків урядовець / посадовець часто може опинитися в неоднозначній ситуації. Наприклад, чи буде прийняття запрошення на вечерю від бізнес-асоціації розцінено як спробу налагодити контакт для подальшого використання адміністративного ресурсу в обхід законних способів? Подібні та інші питання розглядалися в контексті підвищення рівня довіри до уряду. Важливо, що було зазначено й спосіб викриття економічних інтересів державних службовців. Так, на форумі Антикорупційної школи дійшли згоди, що громадськість повинна мати безперешкодний доступ до електронних декларацій, а інформацію з цих декларацій потрібно ретельно перевіряти, адже непоодинокими є випадки, коли держслужбовець вказує в декларації нісенітницю щодо своїх активів, маючи завчасно вигадану відмовку, й усі громадяни це сприймають спокійно;

2) більш дієве функціонування Закону України «Про доступ до публічної інформації» [8]. Зараз частина інформації, пов'язаної із виконанням службових обов' язків посадовцем, не є відкритою. Навіть більше, на запити, сформовані відповідно до законодавства, відповідають відмовами із посиланням на якісь неточності запиту бюрократичного характеру або взагалі не відповідають. Попри це, доступ до такої інформації дасть змогу розкрити безліч корумпованих дій, зв'язки депутатів з тим чи іншим бізнесом, відповідність способу життя депутата його фактичним доходам тощо. Важливо, аби Закон України «Про доступ до публічної інформації» працював, адже в Україні кожен громадянин має право доступу до такої інформації. Майже будь-яка інформація стосовно урядовців як публічних осіб не повинна замовчуватися;

3) одним з пріоритетних шляхів протидії корупції визнано поглиблену децентралізацію, що пояснюється тим, що громада на місцях зможе більш якісно викорінити корупцію;

4) запропоновано створити та наділити необхідними повноваженнями певні наглядові ради при лікарнях, адже медична сфера одна з найбільш корумпованих. Наглядова рада повинна здійснювати контроль за рухом фінансових коштів у лікарнях, унеможливлювати хабарництво та схеми отримання «відкатів». Необхідно створити для зазначеного органу відповідну нормативну базу, аби його діяльність не була суто декларативною;

5) висунуто думку щодо впровадження більшої кількості ресурсів на кшталт Prozoro, YouControl та інших. Це пояснюється тим, що за допомогою подібних ресурсів можна попередити корупційні схеми та зробити тендерну діяльність більш прозорою. Наслідком прозорості закупівель матеріалів стане покращення інфраструктури, адже об’єктом розкрадання найчастіше є кошти, виділені на благоустрій. Наприклад, урядовці часто ділять кошти, передбачені на ремонт доріг, зрештою, замість якісного асфальту кладуть дешеві матеріали, й дорожнє покриття потребує нового ремонту вже за декілька місяців.

Загалом робота, проведена в межах Антикорупційної школи громадськими активістами, є доволі змістовною, а отримані висновки у вигляді тез цілком можна розглядати як види шляхів протидії корупції в Україні. Тісна співпраця уряду з подібними форумами дала б змогу разом віднайти найкращі шляхи подолання корупційних проявів в Україні.

Крім того, не варто оминати увагою й зарубіжний досвід щодо шляхів протидії корупції, який можна було застосувати у вітчизняному законодавстві та впровадити у вітчизняну антикорупційну доктрину.

Наприклад, у Бельгії місцеві урядовці користуються Кодексом поведінки (в Україні аналогом можуть бути, наприклад, Правила адвокатської етики). Згідно із цим Кодексом будь-які дії корумпованого характеру не допускаються й особа, яка взяла участь у корупційній схемі, повинна зізнатися в цьому, аби отримати найменш суворе покарання. Звісно, урядовець, який був учасником корупційної схеми, звільняється з посади без права обіймати подібну посаду до кінця життя. Подібний Кодекс сприймається дещо утопічно в умовах українських реалій, хоча в Бельгії, й справді, були випадки добровільного зізнання урядовців / чиновників у корупційних правопорушеннях [2, с. 72].

Водночас у Німеччині активно працюють спеціальні телефонні лінії, куди можна надіслати анонімний сигнал щодо факту корупції, на який миттєво відреагують уповноважені структури [6, с. 112-113].

Зрозуміло, що явище корупції майже неможливо повністю знищити, й у європейських державах вона також існує, про що свідчать антикорупційні скандали, які періодично виникають там і спричиняють багато галасу. Один з останніх прикладів - арешт відомого футбольного чиновника, француза Мішеля Платіні, який підозрюється в отриманні хабара у великому розмірі за зловживання своїми службовими обов'язками (допомога Катару отримати право на проведення Чемпіонату світу з футболу 2022 року не через конкурсну основу, а за певну суму грошей).

Висновки. Отже, підсумовуючи викладене в цьому дослідженні й на підставі проаналізованих масивів інформації, вважаємо за необхідне виокремити такі шляхи протидії корупції в Україні:

- створити при Міністерстві юстиції України постійно діючий науково-дослідницький комітет, який має вивчати явище корупції, його видозміни 
та розробляти наукові методи запобігання корупції на підставі даних, отриманих шляхом наукових досліджень;

- надалі розвивати систему спеціальних антикорупційних органів, більш чітко прописувати їх повноваження, нормативно закріпляти принципи взаємодії цих органів (слід зауважити, що НАБУ зараз має в цілому позитивні відгуки за наслідками своєї діяльності);

- активізувати роботу антикорупційних органів, уповноважених на проведення антикорупційної експертизи нормативно-правових актів та рішень державних органів влади, органів місцевого самоврядування (Обов'язкова антикорупційна експертиза здійснюється Міністерством юстиції України, крім антикорупційної експертизи проектів нормативно-правових актів, внесених на розгляд Верховної Ради України народними депутатами України, яка здійснюється комітетом Верховної Ради України, до предмета відання якого належить питання боротьби з корупцією);

- вчиняти дії, спрямовані на підвищення культури громадян, формувати й розвивати їх антикорупційну культуру (розвиток крайньої нетерпимості до явища корупції);

- розвивати загальнодержавну Стратегію антикорупційного розвитку країни, яка повинна бути сучасною та прогресивною;

- створювати та активно впроваджувати більше ресурсів на кшталт Prozoro та подібних йому;

- здійснювати просвітницьку діяльність щодо явища корупції серед населення, підвищуючи обізнаність останнього щодо корупції та сприяти формуванню негативного ставлення до корупції загалом;

- використовувати успішний міжнародний досвід у протидії корупції.

\section{Jimepamypa}

1. Багрий-Шахматов Л.В. Уголовно-правовые и криминологические проблемы коррупции, теневой экономики и борьбы с ними : учеб. пособие. Одесса : Латстар, 2001. 530 с.

2. Ільєнок Т.В. Боротьба з корупцією: міжнародний досвід. Юридична наука. 2013. № 2. С. 71-77. URL: http://nbuv.gov.ua/UJRN/jnn_2013_2_11.

3. Костенко О.М. Корупція кризового типу: поняття і шляхи протидії. Боротьба з організованою злочинністю і корупиією (теорія $і$ практика). 2008. Вип. 18. С. 136-141. URL: http://nbuv.gov.ua/UJRN/ boz $200818 \quad 15$.

$\overline{4}$. Костенко О.М. Культура і закон - у протидії злу. Київ : Атіка, 2008. 352 с.

5. Кримінологія : підруч. для студ. вищ. навч. закл. / О.М. Джужа, Я.Ю. Кондратьєв, О.Г. Кулик, П.П. Михайленко та ін. ; за заг. ред. О.М. Джужі. Київ : Юрінком Інтер, 2002. 416 с.

6. Мельник M.I. Німеччина на шляху боротьби з корупцією. Право України. 1997. № 11. С. 111-115.

7. П'ять способів боротьби 3 корупцією: Антикорупційна школа надає українським активістам ефек- тивні інструменти / Україна : інформ. сайт. URL: http://www.ua.undp.org/content/ukraine/uk/home/ presscenter/articles/2018/five-ways-to-fight-graft. html.

8. Про доступ до публічної інформації : Закон України від 13.01.2011 № 2939-VI. Відомості Верховної Ради Украӥни (ВВР). 2011. № 32. Ст. 314.

9. Уряд схвалив проект Закону України «Про Антикорупційну стратегію на 2018-2020 роки» / Урядовий портал. URL: https://www.kmu.gov.ua/ua/news/uryadshvaliv-proekt-zakonu-ukrayini-pro-antikorupcijnustrategiyu-na-2018-2020-roki.

\section{Анотація}

Однолько І. В. ІШляхи протидії корупції в Україні (механізм реагування). - Стаття.

Стаття присвячена розгляду існуючих шляхів протидії корупції в Україні та розробці на цій основі механізмів реагування на корупційну злочинність через виконання завдань, пов'язаних з аналізом здобутків вітчизняних та зарубіжних науковців щодо загальнодержавних шляхів запобігання та необхідності здійснення заходів на зменшення корупційної активності громадян.

Визначено важливість підвищення антикорупційної культури населення для формування негативного ставлення в суспільстві до явища корупції, проаналізовано наукові підходи до визначення механізму реагування на корупційні правопорушення, проаналізовано міжнародний досвід реагування на корупційні прояви.

Розкритонауковеобгрунтуванняпевних шляхівпротидії корупції в українській державі, а також на основі проведеного дослідження запропоновано авторське бачення протидії корупції, а також підтримано позицію провідних українських кримінологів щодо ефективної протидії корупції через прояв політичної волі, спрямованої на реальну протидію зазначеному виду злочинів.

Окремо зазначається, що ефективна протидія корупції можлива лише за умови комплексного підходу до мінімізації цього явища. Для цього потрібно шляхом проведення просвітницької роботи сформувати негативне ставлення до корупційних правопорушень громадян. Необхідним є використання сучасних ресурсів, які дають змогу мінімізувати можливість застосування корупційних схем.

Як підсумок визначено, що в Україні, яка обрала зараз вектор на успішну євроінтеграцію, потрібно належним чином підходити до викорінення явища корупції, використовуючи увесь можливий арсенал способів та заходів запобігання. Найбільш ефективними шляхами протидії корупції сьогодні є формування антикорупційної культури населення, використання міжнародного досвіду та застосування більшої кількості ресурсів, спрямованих на мінімізацію корупційних ризиків, а також реалізація загальнонаціональної стратегії держави щодо подолання цього явища.

Ключові слова: шляхи протидії корупції, механізм реагування, антикорупційна культура, міжнародний досвід, просвітницька діяльність, сучасна Україна, загальнодержавна антикорупційна стратегія.

\section{Summary}

Odnolko I. V. Ways to counter corruption in Ukraine (mechanism of response). - Article.

The article is devoted to reviewing the existing ways of combating corruption in Ukraine and developing on this basis mechanisms for responding to corruption crime through the implementation of tasks related to the analysis of the achievements of national and foreign 
scientists on the national ways of preventing and the need to take measures to reduce corruption.

It is noted the importance of increasing anti-corruption culture among the population, in order to form a negative attitude in society towards the phenomenon of corruption, analyzed scientific approaches to determination the mechanism for responding to corruption offenses, and considered international experience in responding to corruption.

The scientific substantiation of certain ways of counteracting corruption in the Ukrainian state is revealed, as well as on the basis of the conducted research the author's vision of counteracting corruption is offered, as well as the position of leading Ukrainian criminologists on the effective counteraction of corruption aimed at counteracting the said type is supported.

The author reveals the scientific rationale for certain ways to counter corruption in Ukraine, as well as offers own vision of counteraction corruption based on the study.

It is drawn attention to the fact that effective countering of corruption is possible only if an integrated approach is taken to eradicate this phenomenon. Negative attitudes towards corruption offenses should be formed among citizens by conducting educational work aimed at such formation. There is a need to use modern resources that minimize the possibility of using corruption schemes.

As a result, it is determined that Ukraine, in its modern realities with a vector for successful European integration, should give serious consideration to eradicate the phenomenon of corruption, using the whole possible arsenal of methods of such eradication and prevention measures. The most effective ways to counteract corruption today are the formation of an anti-corruption culture of the population, the use of international experience and the use of greater number of resources aimed at minimizing corruption risks as well as the implementation of the national strategy of the state to overcome this phenomenon.

Key words: ways of anti-corruption actions, mechanism of response, anti-corruption culture, international experience, educational activities, modern Ukraine, national anti-corruption strategy. 